\title{
In vitro antioxidant and antinociceptive potentialities of methanolic extract of Litsea glutinosa
}

\author{
N. N. Rumzhum*, M. M. Rahman, A. A. Sharukh, S. A. Chowdhury and M. N. Parvin \\ Laboratory of Pharmacognosy and Pharmacology, Department of Pharmacy, \\ Stamford University, Dhaka-1217, Bangladesh.
}

\begin{abstract}
The methanolic extract of Litsea glutinosa (Lauraceae) was evaluated for in vitro antioxidant activity by determination of hydrogen peroxide scavenging activity, total antioxidant capacity, assay of nitric oxide scavenging activity and reducing power test and in vivo antinociceptive effect in acetic acid induced writhing model in swiss albino mice. The results revealed the presence of pronounced antioxidant property as compared with ascorbic acid used as standard and a dose-dependent ( 250 and $500 \mathrm{mg} / \mathrm{kg}$ ) analgesic effect. The antioxidant and antinociceptive properties observed seem to be in good accordance with the traditional uses of Litsea glutinosa.
\end{abstract}

Keywords: Litsea glutinosa; Lauraceae; Antioxidant; Antinociceptive; Swiss albino mice.

\section{Introduction}

The use of plants as a source of raw materials for medicine is an ancient one. The importance of plants in medicine remains even of greater relevance with the current global shift to obtain drugs from plant sources, as a result of which attention has been given to the medicinal value of herbal remedies for safety, efficacy and economy (Glombitza et al. 1993). Chemical principles from natural sources have become much simpler and have contributed significantly to the development of new drugs from medicinal plants (Cox and Balick, 1994). The plants that are used in traditional medicines are likely and in some cases already known, to contain pharmacologically active compounds, which differ widely in terms of structures and therapeutic properties. Therefore considerable importance has been placed on the screening of these plants for active or lead compounds. Evaluation of the local flora exploited in traditional medicine for various biological activities is a necessary step in the isolation and characterization of the active principles and further leading to drug development (Rahman et al. 2011). A large number of plants have been screened as a viable source of natural antioxidants including tocopherols, vitamin $\mathrm{C}$, carotenoids and phenolic compounds which are responsible for the maintenance of health, helping the human body to reduce oxidative damage and the protection from coronary heart diseases and cancer (Yanga et al. 2002). In view of these Litsea glutinosa was studied for its potential antioxidant and analgesic effects.

*Corresponding author. E-mail: nowshin.nowaz@yahoo.com
Litsea glutinosa (Common name: Indian laurel, Bengali name: Menda pata; Family- Lauraceae) is a moderately sized tree which grows to a height of about 20 to 30 feet. It is found mainly in India and South China to Malaysia, Australia and the Western pacific islands. Previous phytochemical studies revealed the presence of alkaloids (Hart et al. 1969; Bhakuni and Gupta, 1983; Holloway and Scheinmann, 1973), butanolides (Cheng et al. 2001; Chen et al. 1998), and sesquiterpenoids (Hoang et al. 2002; Zhang et al. 2001; Zhang et al. 2003a; Zhang et al. 2003b) in the genus Litsea. Few records are found in the literature with respect to the isolation of flavonoids from Litsea species (Wang et al. 2009). Its bark and leaves are used as a demulcent and mild astringent for diarrhea and dysentery and the roots are used to poultice sprains and bruises (Wang et al. 2010). In this paper, the antioxidant and the antinociceptive properties of the methanolic extract of Litsea glutinosa are being reported to justify the traditional use of this plant through in vitro and in vivo evaluation.

\section{Materials and methods}

\section{Plant materials}

Leaves of Litsea glutinosa were collected from Sylhet in June 2008 and were identified by Ms. Hosne Ara, Director, 
Bangladesh National Herbarium (BNH), Mirpur, Dhaka. A voucher specimen was prepared and deposited at $\mathrm{BNH}$ (DACB accession no: 32777).

\section{Extraction of plant materials}

About $140 \mathrm{~g}$ of dried and powered leaves was soaked in $1 \mathrm{~L}$ of $90 \%$ methanol for several days. The extract was filtered and concentrated to a gummy mass (6 g). Different chemical tests revealed the presence of alkaloids, flavonoids, saponins and tannins (Evans, 1989) in this extract.

\section{Antioxidant properties}

\section{i) Qualitative assay}

A suitably diluted stock solutions (sample solutions) were spotted on pre-coated Silica gel TLC (Thin layer chromatography) plates and the plates were developed in solvent systems of different polarities (polar, medium polar and nonpolar) to resolve polar and non-polar components of the extract and to choose the solvent system in which stock solutions run well. The plates were dried at room temperature and were sprayed with $0.02 \%$ DPPH in ethanol. Bleaching of DPPH by the resolved bands was observed for 10 minutes and the color changes (yellow on purple background) were noted (Sadhu et al. 2003).

\section{ii) Quantitative assay}

Free radical scavenging activity of the methanol extract was evaluated by determination of total antioxidant capacity, assay of nitric oxide scavenging activity and reducing power test. In all methods ascorbic acid is used as standard.

\section{Scavenging of hydrogen peroxide}

The ability of the methanolic extract of Litsea glutinosa to scavenge hydrogen peroxide was determined according to the method of Ruch et al. (1989). A solution of hydrogen peroxide $(2 \mathrm{mmol} / \mathrm{l})$ was prepared in phosphate buffer $(\mathrm{pH}$ 7.4). Hydrogen peroxide concentration was determined spectrophotometrically from absorption at $230 \mathrm{~nm}$ with molar absorbtivity $81(\mathrm{~mol} / 1)^{-1} \mathrm{~cm}^{-1}$ in a spectrophotometer (Hach, DR-4000U). Extracts $(50-250 \mathrm{mg} / \mathrm{ml})$ in distilled water were added to a hydrogen peroxide solution $(0.6 \mathrm{ml}$, $40 \mathrm{mM}$ ). Absorbance of hydrogen peroxide at $230 \mathrm{~nm}$ was determined after ten minute against a blank solution containing in phosphate buffer without hydrogen peroxide. For each concentration, a separate blank sample was used for background subtraction. The percentage of scavenging of hydro- gen peroxide of methanolic extract of Litsea glutinosa and standard compounds was calculated using the following equation:

Percent scavenged $\left[\mathrm{H}_{2} \mathrm{O}_{2}\right]=\left(\mathrm{A}_{0}-\mathrm{A}_{1}\right) / \mathrm{A}_{0} \times 100$

Where, $A_{0}$ was the absorbance of the control and $A_{1}$ was the absorbance in the presence of methanolic extract of Litsea glutinosa and standards (Gülçin et al. 2003).

\section{b. Determination of total antioxidant capacity}

The antioxidant activity of the extract was evaluated by the phosphomolybdenum method according to the procedure of Prieto et al. (1999). The assay is based on the reduction of $\mathrm{Mo}(\mathrm{VI})$ - Mo(V) by the extract and subsequent formation of a green phosphate / $\mathrm{Mo}(\mathrm{V})$ complex at acid $\mathrm{pH} .0 .3 \mathrm{ml}$ extract was combined with $3 \mathrm{ml}$ of reagent solution $(0.6 \mathrm{M}$ sulfuric acid, $28 \mathrm{mM}$ sodium phosphate and $4 \mathrm{mM}$ ammonium molybdate). The tubes containing the reaction solution were incubated at $95{ }^{\circ} \mathrm{C}$ for $90 \mathrm{~min}$. Then the absorbance of the solution was measured at $695 \mathrm{~nm}$ using a spectrophotometer (Hach, DR-4000U) against blank after cooling to room temperature. Methanol $(0.3 \mathrm{ml})$ in the place of extract is used as the blank. The antioxidant activity is expressed as the number of equivalents of ascorbic acid.

\section{Assay of Nitric oxide scavenging activity}

The procedure is based on the method, where sodium nitroprusside in aqueous solution at physiological $\mathrm{pH}$ spontaneously generates nitric oxide, which interacts with oxygen to produce nitrite ions that can be estimated using Greiss reagent. Scavengers of nitric oxide compete with oxygen leading to reduced production of nitrite ions. For the experiment, sodium nitroprusside $(10 \mathrm{mM})$ in phosphate buffered saline was mixed with different concentrations of methanolic extract of Litsea glutinosa dissolved in methanol and incubated at room temperature for $150 \mathrm{~min}$. The same reaction mixture without the methanol extract but the equivalent amount of methanol served as the control. After the incubation period, $0.5 \mathrm{ml}$ of Griess reagent (1\% sulfanilamide, $2 \%$ $\mathrm{H}_{3} \mathrm{PO}_{4}$ and $0.1 \% \mathrm{~N}-(1-$ naphthyl) ethylenediamine dihydrochloride) was added. The absorbance of the chromophore formed was read at $546 \mathrm{~nm}$ (Sreejayan and Rao, 1997).

\section{Reducing power}

The reducing power of methanolic extract was determined according to the method of Oyaizu (1986). Different 
amounts of methanolic extracts $(50-250 \mathrm{mg})$ in $1 \mathrm{ml}$ of methanol were mixed with phosphate buffer $(2.5 \mathrm{ml}, 0.2$ $\mathrm{mol} / \mathrm{l}, \mathrm{pH} 6.6)$ and potassium ferricyanide $\left[\mathrm{K}_{3} \mathrm{Fe}(\mathrm{CN})_{6}\right](2.5$ $\mathrm{ml}, 1 \%$ ). The mixture was incubated at $50^{\circ} \mathrm{C}$ for $20 \mathrm{~min}$. A portion $(2.5 \mathrm{ml})$ of trichloroacetic acid $(10 \%)$ was added to the mixture, which was then centrifuged $(650 \mathrm{x} g$ at room temperature) for $10 \mathrm{~min}$. The upper layer of solution $(2.5 \mathrm{ml})$ was mixed with distilled water $(2.5 \mathrm{ml})$ and $\mathrm{FeCl}_{3}(0.5 \mathrm{ml}$, $0.1 \%$ ), and the absorbance was measured at $700 \mathrm{~nm}$. Increased absorbance of the reaction mixture indicated increased reducing power.

\section{Antinociceptive properties}

Evaluation of antinociceptive effect was performed by acetic acid induced writhing model in mice (Whittle, 1964). The acetic acid induced writhing method is an analgesic behavioral observation assessment method that demonstrates a noxious stimulation in mice. The test consists of injecting the $0.7 \%$ acetic acid solution intraperitoneally and then observing the animal for specific contraction of body referred as 'writhing'. A comparison of writhing was made with the positive control (Diclofenac-Na). Control and test samples are given orally 30 minutes prior to acetic acid injection. If the sample possesses analgesic activity, the animal that received the sample will give lower number of writhing than the control, i.e. the sample having analgesic activity will inhibit writhing.

\section{Results and discussion \\ Antioxidant properties}

i) Qualitative assay: The color changes (yellow on purple background) on the TLC plates were observed due to the bleaching of DPPH by the resolved bands.

\section{Quantitative assay}

\section{Scavenging of hydrogen peroxide}

Scavenging of $\mathrm{H}_{2} \mathrm{O}_{2}$ by extracts may be attributed to their phenolic constituents, which can donate electrons to $\mathrm{H}_{2} \mathrm{O}_{2}$, thus neutralizing it to water. The methanolic extracts of Litsea glutinosa were capable of scavenging hydrogen peroxide in a concentration-dependent manner (Fig. I).

\section{Total antioxidant capacity}

Total antioxidant capacity exerted by the extract is concentration dependent. It is observed that the extract is likely to

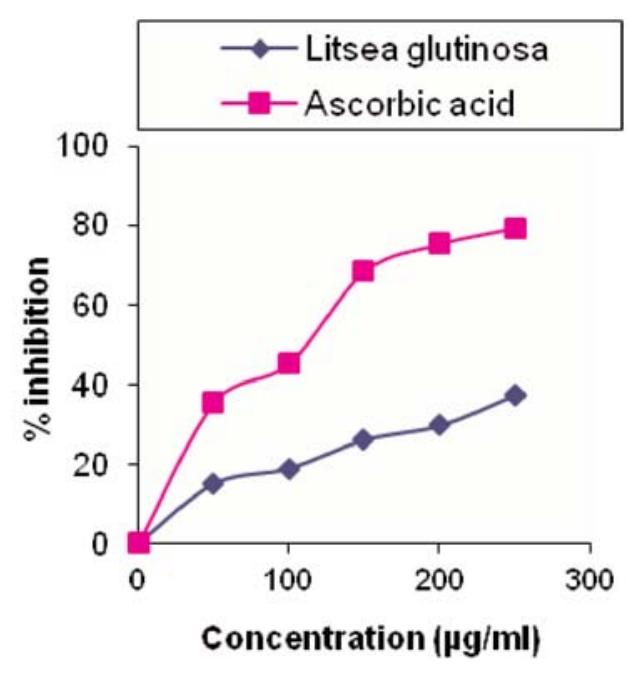

Fig. 1. $\mathrm{H}_{2} \mathrm{O}_{2}$ scavenging activity of methanolic extract of Litsea glutinosa Vs Ascorbic acid

have the capacity of reduction of $\mathrm{Mo}(\mathrm{VI})$ to $\mathrm{Mo}(\mathrm{V})$ by the antioxidant principle and the formation of a green phosphate / Mo(V) complex with a maximal absorption at $695 \mathrm{~nm}$. The antioxidant activity is expressed as the number of equivalents of ascorbic acid (Table I).

Table I. Total antioxidant capacity of methanolic extract of Litsea glutinosa

\begin{tabular}{ccc}
\hline Materials & $\begin{array}{c}\text { Concentration } \\
(\mu \mathrm{g} / \mathrm{mL})\end{array}$ & $\begin{array}{c}\text { Equivalent to } \\
\text { ascorbic acid }\end{array}$ \\
\hline Methanol extract of & 62.50 & $0.179 \pm 0.12$ \\
Litsea glutinosa & 125.0 & $0.257 \pm 0.03$ \\
& 250.0 & $0.387 \pm 0.07$ \\
& 500.0 & $0.501 \pm 0.16$ \\
& 1000.0 & $1.031 \pm 0.11$ \\
\hline
\end{tabular}

Nitric oxide scavenging activity

From Fig. II, it is observed that the extract is likely to have concentration dependent nitric oxide scavenging activity. The leaves may have the property to counteract the effect of NO formation and in turn may be of considerable interest in preventing the ill effects of excessive NO generation in the human body. Further, the scavenging activity may also help to arrest the chain of reactions initiated by excess generation of NO that are detrimental to the human health. Nitric oxide is also implicated for inflammation, cancer and other pathological conditions (Moncada et al. 1991). 


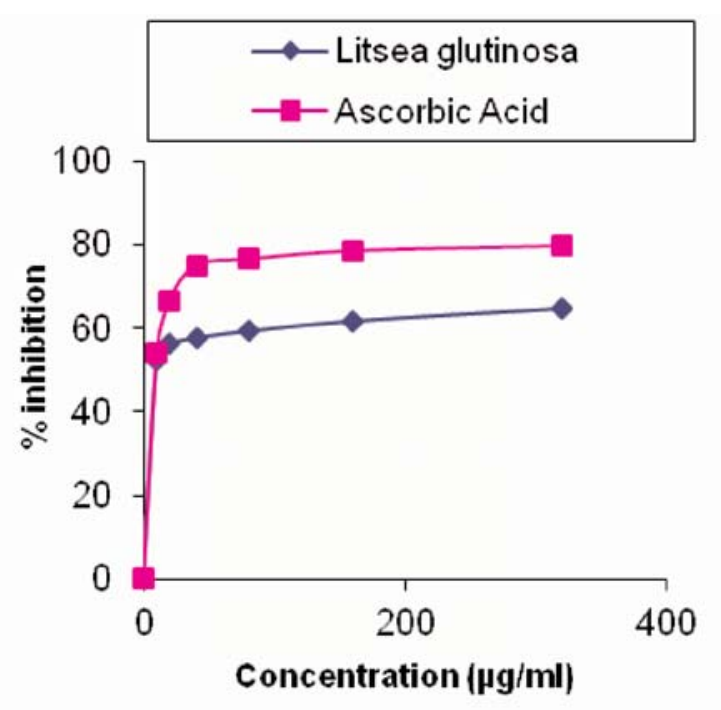

Fig. II. Nitric oxide scavenging activity of methanolic extract of Litsea glutinosa

Reducing power

Reduction ability of the extract has been investigated from the $\mathrm{Fe}^{+++}-\mathrm{Fe}^{++}$transformation using the method followed by Oyaizu (1986). Duh (1998) and Tanaka et al. (1988) have observed a direct correlation between antioxidant activity

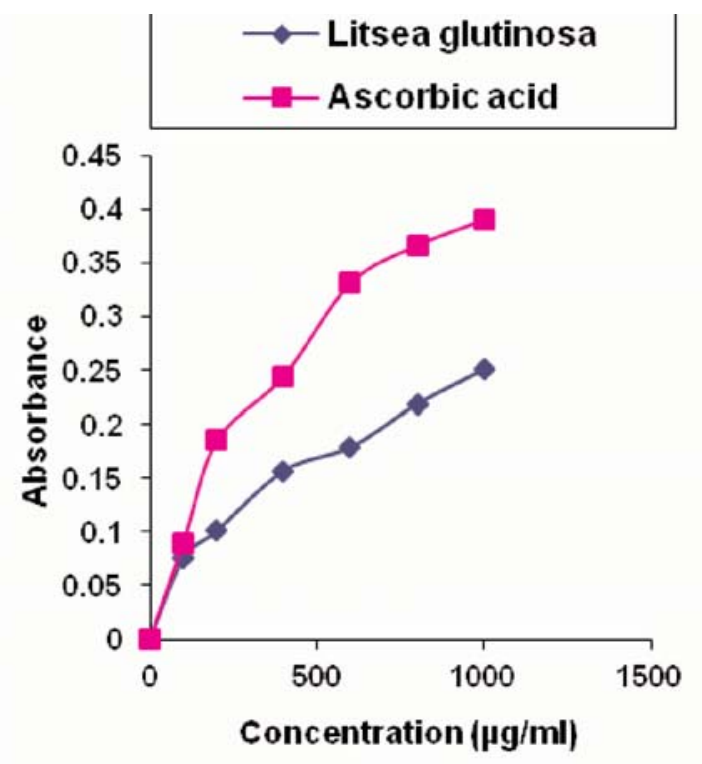

Fig. III. The reducing power of methanolic extract of Litsea glutinosa and reducing power of certain plant extracts. The reducing properties are generally associated with the presence of reductones (Duh, 1998) which have been shown to exert antioxidant action by breaking the free radical chain by donating a hydrogen atom (Gordon, 1990). Reductones are also reported to react with certain precursors of peroxide, thus preventing peroxide formation. Fig. III shows the reduction ability of Litsea glutinosa.

\section{Antinociceptive properties}

In acetic acid induced mice, the methanolic extract produced $69.57 \%$ and $86.96 \%$ writhing inhibition at the doses of 250 $\mathrm{mg} / \mathrm{kg}$ and $500 \mathrm{mg} / \mathrm{kg}$ body weight respectively, whereas Diclofenac sodium produced $45.65 \%$ inhibition at the dose of $25 \mathrm{mg} / \mathrm{kg}$. Table II shows the antinociceptive effect of Litsea glutinosa.

Table II. Antinociceptive property of methanolic extract of Litsea glutinosa in acetic acid induced writhing in mice

\begin{tabular}{lcc}
\hline \multicolumn{1}{c}{$\begin{array}{c}\text { Animal } \\
\text { group/Treatment }\end{array}$} & $\begin{array}{c}\text { Concentration } \\
(\mu \mathrm{g} / \mathrm{mL})\end{array}$ & $\begin{array}{c}\text { Equivalent to } \\
\text { ascorbic acid }\end{array}$ \\
\hline $\begin{array}{l}\text { Control } \\
\text { 1\% Tween-80 solution }\end{array}$ & $\begin{array}{c}230.01^{\mathrm{a}} \\
\text { in water, }\end{array}$ & -- \\
$10 \mathrm{ml} / \mathrm{kg}$, p.o. \\
$\mathrm{n}=4$
\end{tabular}

Values are expressed as mean \pm S.E.M.; a, indicates $\mathrm{P}<0.001$ vs. control; p.o.: per oral.

A combination of antioxidants with analgesics normalized the oxidative stress which suggests that the administration of antioxidants in pain treatment may be employed to decrease the doses of analgesics (Rokytal et al. 2003). Antioxidant- 
based pain killers may be a viable alternative in future to addictive medications such as morphine. Therefore, medicinal plants like Litsea glutinosa which possesses both antioxidant and antinociceptive properties can be used in the treatment of pain stimulated oxidative stress condition through their pharmacological validation.

\section{Conclusion}

Our present study demonstrates the antioxidant and antinociceptive properties of Litsea glutinosa and justifies its use in traditional medicine.

\section{Acknowledment}

Authors are grateful to the authority of Stamford University Bangladesh for their support to perform these investigations.

\section{References}

Bhakuni DS and Gupta S (1983), Alkaloids of Litsea wightiana. Planta Med. 48 (1): 52-54.

Cheng HI, Lin WY, Duh CY, Lee KH, Tsai IL and Chen IS (2001), New cytotoxic butanolides from Litsea acutivena. J. Nat. Prod. 64 (12): 1502-1505.

Chen IS, Lai-Yaun IL, Duh CY and Tsai IL (1998), Cytotoxic butanolides from Litsea akoensis. Phytochemistry. 49: 745-750.

Cox P and Balick M (1994), The ethnobotanical approach to drug discovery. Scientific American. 270: 82-87.

Duh PD (1998), Antioxidant activity of burdock (Arctium lappa Linne): its scavenging effect on free radical and active oxygen. Journal of the American Oil Chemist's Society. 75 (4): 455-461.

Evans WC (1989), Trease and Evan's Text book of Pharmacognosy. 13th Ed. (University Press, Cambridge) 1989, pp 546.

Glombitza KW, Mahran G.H, Mirhom YW, Michael KG and Motawi TK (1993), Hypoglycemic and Antihypergly cemic effects of Zizyphus spinachristi in rats. Planta Med. 60: 244-247.

Gordon MH (1990), The mechanism of antioxidant action in vitro. In BJF: Hudson Ed. (Elsevier Applied Science, London) 1990, pp 1.
Gülçin I, Oktay M, Kirecci E and Küfrevioglu ÖI (2003), Screening of antioxidant and antimicrobial activities of anise (Pimpinella anisum L.) seed extracts. Food Chem. 83: 371-382.

Hart NK, Johns SR, Lamberton JA, Loder JW, Moorhouse A, Sioumis AA and Smith TK (1969), Alkaloids of several Litsea species from New Guinea. Aust. J. Chem. 22 (10): 2259-2262.

Hoang VD, Tan GT, Zhang HJ, Tamez PA, Hung NV, Cuong NM, Soejarto DD, Fong HHS and Pezzuto JM (2002), Natural anti-HIV agents. Part I. (+)-demethoxyepiexcelsin and verticillatol from Litsea verticillata. Phytochemistry. 59: 325-329.

Holloway DW and Scheinmann F (1973), Co-occurrence of aporphine and biphenyl constituents in Litsea turfosa. Phytochemistry. 12: 1503-1505.

Moncada A, Palmer RMJ and Higgs EA (1991). Nitric oxide: physiology, pathophysiology and pharmacology. Pharmacological Reviews. 43 (2): 109-142.

Oyaizu M (1986), Studies on product of browning reaction prepared from glucose amine. Japanese Journal of Nutrition. 44 (6): 307-315.

Prieto P, Pineda M and Aguilar M (1999), Spectrophotometric quantitation of antioxidant capacity through the formation of a phosphomolybdenum complex: Specific application to the determination of vitamin E. Anal. Biochem. 269 (2): 337-341.

Rahman MM, Habib MR, Hasan SMR, Sayeed MA and Rana MS (2011), Antibacterial, Cytotoxic and Antioxidant potential of Methanolic extract of Phyllanthus acidus L Int. J Drug Dev. \& Res. 3 (2): 154-161.

Rokyta1 R, Holecek V, Pekarkova I, Krejcova J, Racek J, Trefi L and Yamamotova A. (2003), Free radicals after painful stimulation are influenced by antioxidants and analgesics. Neuro endocrinel. Lett. 24 (5): 304-309.

Ruch RJ, Cheng SJ and Klaunig JF (1989), Prevention of cytotoxicity and inhibition of intracellular communication by antioxidant catechins isolated from Chinese green tea. Carcinogenesis. 10: 1003-1008. 
Sadhu SK, Okuyama E, Fujimoto H and Ishibashi M. (2003), Separation of Leucas aspera, a Medicinal Plant of Bangladesh, Guided by Prostaglandin Inhibitory and Antioxidant Activities. Chem. Pharm. Bull. 51 (5): 595-598.

Sreejayan N and Rao MNA (1997). Nitric oxide scavenging by curcuminoids. J. Pharm. Pharmacol. 49 (1): 105107.

Tanaka M, Kuie CW, Nagashima Y and Taguchi T (1988), Applications of antioxidative Maillard reaction products from histidine and glucose to sardine products. Bulletin of the Japanese Society of Scientific Fisheries. 54 (8): 1409-1414.

Wang JQ, Li J, Zou YH, Cheng WM, Lu C, Zhang L, Ge JF, Huang C, Jin Y, Lu XW, Hu CM and Liu LP (2009), Preventive effects of total flavonoids of Litsea coreana leve on hepatic steatosis in rats fed with high fat diet. J. Ethnopharmacol. 121 (1): 54-60.

Wang YS, Huang R, Lu H, Li FY and Yang JH (2010), A New 2' Oxygenated Flavone Glycoside from Litsea glutinosa (Lour.) C B. Rob. Biosci. Biotechnol. Biochem. 74 (3): 652-654.

Whittle BA (1964), The use of changes in capillary permeability in mice to distinguish between narcotic and non-narcotic analgesics. Br. J. Pharmacol. Chemother. 22 (2): 246-253.
Yanga JH, Linb HC and Maub JL (2002), Antioxidant properties of several commercial mushrooms. Food Chem. 77: 229-235.

Zhang HJ, Tan GT, Hoang VD, Hung NV, Cuong NM, Soejarto DD, Pezzuto JM and Fong HHS (2001),

Natural anti-HIV agents. Part II. Litseaverticillol A, a prototypic litseane sesquiterpene from Litsea verticillata. Tetrahedr. Lett. 42 (49): 8587-8591.

Zhang HJ, Tan GT, Hoang VD, Hung NV, Cuong NM, Soejarto DD, Pezzuto JM and Fong HHS (2003a), Natural anti-HIV agents. Part III. Litseaverticillols A$\mathrm{H}$, novel sesquiterpenes from Litsea verticillata. Tetrahedr. Lett. 59 (2): 141-148.

Zhang HJ, Tan GT, Santarsiero BD, Mesecar AD, Hung NV, Cuong NM, Soejarto DD, Pezzuto JM and Fong HHS (2003b).. New sesquiterpenes from Litsea verticillata. J. Nat. Prod. 66 (5): 609-615.

Received: 27 October 2011; Revised: 08 January 2012; Accepted: 26 February 2012 . 